\title{
Penggunaan Metode Berfikir-Berpasangan-Berbagi (Think Pair Share) Untuk Meningkatkan Hasil Belajar Bahasa Indonesia Materi Cerpen Siswa Kelas IX-C SMP Negeri 1 Cimenyan
}

\author{
Hani Handayani \\ SMP Negeri 1 Cimenyan, Kabupaten Bandung, Jawa Barat \\ hanihandayani@gmail.com
}

\begin{tabular}{|l|}
\hline Abstrak \\
\hline Penelitian ini mempunyai tujuan untuk mengetahui proses pembelajaran khususnya hasil belajar \\
siswa dalam pembelajaran cerita pendek dengan menggunakan model pembelajaran Think pair \\
Share (TPS). Model ini diharapkan bisa meningkatkan hasil belajar siswa terutama dalam \\
pembelajaran cerita pendek. Subjek penelitian ini dilaksanakan dikelas IX-C di SMP Negeri 1 \\
Cimenyan dengan siswa berjumlah 24 orang siswa. Penelitian ini melalui 2 siklus perbaikan. \\
Pada siklus I siswa yang berhasil mendapatkan nilai yang ditetapkan yaitu sebanyak $33 \%$ dengan \\
nilai rata-rata 57. Pemerolehan hasil belajar pada siklus II siswa yang berhasil mencapai KKM \\
$92 \%$ dengan nilai rata-rata 79 dengan kata lain penelitian menggunakan model Pembelajaran \\
Think Pair Share (TPS) dapat meningkatkan hasil belajar siswa kelas IX-C SMP negeri 1 \\
Cimenyan khususnya dalam pembelajaran cerita pendek. \\
Kata Kunci: Bahasa Indonesia.; Hasil Belajar; Model Think Pair Share \\
\hline Abstract \\
\hline The purpose of this study is to describe the process and student learning outcomes in short story \\
learning using the Think Pair Share (TPS) learning model. The model is expected to improve \\
student learning outcomes, especially in short story learning. The subject of this research was \\
carried out in class IX-C at SMP Negeri 1 Cimenyan with 24 students. This research went \\
through 2 cycles of improvement. In the first cycle the score of students who managed to get the \\
KKM score was $33 \%$ with an average score of 57. In the improvement of learning in the second \\
cycle students who managed to reach the KKM $92 \%$ with an average value of 79 in other words \\
this study succeeded in improving student learning outcomes. \\
Keywords: Learning Outcomes; Short Stories; Think Pair Share Learning Model \\
\hline
\end{tabular}

Diterima (11 Agustus 2021) Disetujui (20 Agustus 2021) Dipublikasikan (2 September 2021)

\section{PENDAHULUAN}

Berdasarkan pengamatan yang dilakukan selama mengajar Di SMP Negeri 1 Cimenyan, peneliti menemukan beberapa kendala yang dialami siswa khususnya dalam pemebelajaran Cerita pendek. Beberapa kesulitan yang dialami diantaranya, hasil belajar siswa kurang maksimal pada pembelajaran cerita pendek, kemudian mereka juga kurang memahami isi materi tersebut. Kelemahan peserta didik selama proses pembelajaran cerpen tersebut terutama dalam memahami isi dari cerita pendek tersebut . factor tersebut disebabkan oleh beberapa factor yaitu factor dari peserat didiknya dan guru tersebut. Penggunaan metode ceramah oleh guru saat pembelajaran cerpen tersebut menjadai salah satu factor sebagai panghambat hasil belajar siswa. Sebagai fasilitaror guru harus lebih kreatif dalam menentukan strategi, metode pembelajaran serta Teknik yang tepat dalam menyampaikan pembelajaran cerpen sehingga peserta didik dapat mencapai hasil belajar yang baik.

Untuk mengadaptasi beberapa kendala tersebut guru perlu meningkatkan kreativitasnya dalam menentukan model dan strategi pembelajaran, begitupun dengan peserta didik khusunya siswa kelas IX-C SMP Negeri 1 Cimenyan harus meningkatkan motivasi belajar selama proses pembelajaran di sekolah. Menurut Slavin (dalam Risnawati, 2005:18) pembelajaran kooperatif memfokuskan kepada 
Kerjasama anatar individu dalam kelompok, saling memberikan masukan berupa ide, pendapat serta pamdangan dan tanggung jawab terhadap hasil belajar nya masing-masing. Model pembelajaran kooperatif adalah sebuah model pembelajaran yang sering sekali digunkan oleh para pengajar atau guru, serta mempunyai banyak jenisnya salah satunya yaitu Kooperatif Think pair share (TPS).

Model Think Pair Share adalah jenis pembelajaran kooperatif untuk melatih siswa mengutamakan agar siswa dapat berfikir, berbagi dan bekerja sama dengan siswa lainnya. (Trianto dalam Yustitia dkk, 2018). Menurut Ibrahim, dkk 2005 Langkah-langkah pembelajaran Think pair share di mulai dengan Langkah (1) berfikir atau Thinking itu ranah berfikir dimana proses ini dimulai dengan sebuah pertanyaan serta isu yang berkaiatan dengan materi pembelajaran. Kemudaian Langkah selanjutnya yaitu (2) Berpasangan atau pairing yaitu proses meminta siswa berpasangan dengan siswa yang lain Berpasangan (pairing) pada bagian ini dimulai dengan mengintruksikan peserta didik untuk berpasangan kemudian mendiskusikan hasil pemikiran masing-masing berdasarkan hasil pandangannya pada tahap satu. (3) berbagi atau sharing. Pada tahap ini guru menyuruh pesesrta didik untuk membagi hasil diskusi pasangan tersebut dan menampilkannya didepan kelompok lain. Ini efektif dilakukan dengan cara bergiliran pasangan demi pasangan dan dilanjutkan sampai sekitar seperempat pasangan telah mendapat kesempatan untuk melaporkan Oleh karena itu, peneliti mengambil penelitian tindakan kelas dengan menggunakan metode pembelajaran berfikir, berpasangan-berbagi (Think Pair Share).

Penelitian ini mempunyai tujuan untuk mengetahui proses pembelajaran khususnya hasil belajar siswa dalam pembelajaran cerita pendek dengan menggunakan model pembelajaran Think pair Share (TPS). Model ini diharapkan bisa meningkatkan hasil belajar siswa terutama dalam pembelajaran cerita pendek Siswa kelas IX-C SMP Negeri 1 Cimenyan. Berdasarkan hasil penelitian sebelumnnya yang di jabarakan oleh Ihsan, Muhammad (2010) "Penerapan model think pair share (TPS) untuk meningkatkan motivasi dan hasil belajar siswa pada mata pelajaran bahasa Indonesia kelas X di SMK Bina Cendika Malang" Skripsi Universitas Negeri Malang. Hasil penelitiannya ini menyimpulkan bahwa penerapan model Think Pair Share dapat meningkatkan motivasi belajar siswa dan meningkatkan hasil belajar siswa pada mata pelajaran bahasa Indonesia. Selain itu penelitian juga dilakukan oleh Purnama Desy (2016). Menurut Purnama Desy (2016) Model pembelajaran kooperatif tipe Think Pair Share adalah metode yang berhasil membangun proses pembelajaran peserta didik sehingga peserta didik berfikir kritis. Penggunaan model Berfikir-Berpasangan-Berbagi (Think Pair Share) ini diharapkan membuat hasil belajar peserta didik kelas IX-C SMP Negeri 1 Cimenyan meningkat.

\section{METODE}

Penelitian yang digunakan adalah penelitian tindakan kelas (class action research) yang di ambil dari Desain PTK Kemmis \& Mc. Taggart (1990) yang dikutip oleh Susilo (2009:13) dengan struktur perbaikan pembelajaran yang terdiri dari 2 (dua) siklus. Untuk setiap siklus terdapat 4 fase diantaranya perencanaan, pelaksanaan, pengamatan dan refleksi. Pada penelitian tindakan kelas ini, subjek yang diteliti yaitu siswa kelas IX-C SMP Negeri 1 Cimenyan tahun pelajaran 2019/2020. Sumber data yang diambil adalah seluruh siswa kelas IX-C yang berjumlah 24 orang, yang terdiri dari 16 orang siswa laki-laki dan 8 orang siswa perempuan.

Pelaksanaan perbaikan pembelajaran pra siklus pada pembelajaran membaca cerpen dilaksanakan pada hari Senin, 9 September 2019, siklus pertama dilaksanakan pada hari Senin, 16 September 2019 dan siklus kedua dilaksanakan pada hari Senin, 30 September 2019. Di dalam penyusunan teknik analisis data, skor perolehan siswa yang didapat selama tes diberikan dianalisis secara hitung, Sedangkan perolehan nilai dari observer (pengamat) terhadap kemampuan guru mengelola kelas dalam pembelajaran dianalisis secara deskripsi, (Wardani 2017: 26).

\section{HASIL DAN PEMBAHASAN}

Hasil Sikus 1 
Pada proses perencanaan siklus I ini menghasilkan beberapa perencanaan perbaikan siklus I berdasarkan hasil refleksi pembelajaran pada pelaksanaan pra siklus yang menghasilkan temuan berdasarkan fakta di kelas. Fakta yang diambil yaitu merupakan data-data dari hasil pengamatan teman sejawat peneliti yang memberi penilaian terhadap pelaksanaan pembelajaran di kelas, diantaranya:

- Pada penjelasan konsep Guru hanya sedikit menjelaskan pengertian cerpen serta unsur-unsur intrinsik dan ekstrinsik cerpen.

- Pada penguasaan kompetensi terhadap materi guru seharusnya menguasai materi pelajaran yang dijadikan sebagai objek variabel penelian.

- Pada saat pemberian contoh soal, guru tidak memberikan contoh soal terkait materi karena hal tersebut tidak merasa perlu untuk dikemukakan.

- Pemberian soal latihan dilaksanakan oleh guru diakhir kegiatan inti.

- Pada pemberian tugas mengisi tabel pengamatan mengenai pengertian cerpen serta unsur-unsur intrinsik dan ekstrinsik cerpen. Kegiatan ini guru tidak memberikan tugas pengamatan mengenai materi pembelajaran.

- Pada saat aktivitas pembimbingan guru saat siswa menjawab pertanyaan, guru mengintruksikan kepada peserta didik untuk mencurahkan alasan mengenai pendapat mereka.

- Penggunaan metode mengajar tanya jawab, diskusi, penugasan, think pair share : Ke empat metode pembelajaran tersebut dijalankan oleh guru ketika pembelajaran berlangsung dari awal sampai akhir.

- Penguasaan materi oleh siswa IX-C berdasarkan hasil kegiatan siklus 1 sebanyak $42 \%$ dapat memperoleh hasil diatas KKM hal maka dari itu harus diadakan perbaikan pembelajaran di siklus 2.

- Aktivitas siswa aktif selama pembelajaran hanya beberapa saja, kebanyakan dari mereka belum berani untuk mengutarakan pendapatnya.

- Penggunaan waktu saat proses pembelajaran dirasa guru masih merasa kesulitan untuk menggunakan efektifitas waktu dalam membagi antara kegiatan awal, inti, dan penutup.

- Pada aspek Pemberian evaluasi formatif Berbentuk tes yang diberikan kepada peserta didik yaitu sebanyak 5 soalsebagai penguji keberhasilan pembelajaran.

- Pemberian PR diberikan guru sebanyak 5 buah dengan bentuk uraian untuk meningkatkan pemahaman mereka.

- Media alat peraga yang digunakan berupa Slide Power Point, Kertas HVS, Pensil dan Alat-alat lain penunjang pembelajaran.

Setelah seluruh tahapan pelaksanaan kegiatan siklus 1 terlaksana. Pada siklus 1 ini menghasilkan perolehan nilai siswa setelah kegiatan pembelajaran. Hasil perolehan siswa pada siklus 1 yaitu sebanyak 10 siswa berhasil memperoleh nilai diatas KKM atau sebanyak 43\% dari jumlah keseluruhan. Sedangkat $47 \%$ masih berada di bawah KKM. Dengan rincian siswa yang berhasil melampaui nilai KKM berjumlah $2(8 \%)$ nilai siswa yang mendapat 80, siswa dengan perolehan nilai 70 sebanyak 8 orang (33\%). Adapun nilai peserta didik yang tidak mencapai KKM dan hanya mendapatkan nilai 60 adalah 3 orang dalam persentase yaitu (13\%), sedangkan peserta didik yang mendapat nilai 50 yaitu sebanyak 6 orang saja atatau (25\%), kemudian peserta didik yang mendapat nilai 40 sebnayak 1 orang (4\%), dan peeserta didik yang mendapatkan nilai terkecil yaitu hanya 4 orang (17\%). Dengan kata lain perlu diadakannya perbaikan kembali pada siklus selanjutnya. 


\section{Hasil Siklus 2}

Pada proses perencanaan siklus ke 2 ini peneliti menyiapkan perencanaan yang betujuan sebagai perbaikan pembelajaran. Perbaikan pembelajaran ini berdasarkan rekomendasi dari refleksi siklus ke I. Rencana perbaikan siklus 2 ini dijalankan sesuai dengan kegiatan pada RPP siklus 2 yang telah disusun sebelumnya. Adapun hasil temuan pada siklus 2 adalah sebagai berikut:

- Pada penjelasan konsep oleh guru: Guru menjelaskan pengertian cerpen serta unsur-unsur intrinsik dan ekstrinsik cerpen dengan jelas.

- Pada penguasaan guru terhadap materi: Guru menguasai materi pelajaran yang dijadikan sebagai objek variabel penelian.

- Pada pemberian contoh soal: Guru memberikan contoh soal terkait materi.

- Pada pemberian latihan untuk mengerjakan beberapa soal: Pemberian soal latihan dilaksanakan oleh guru diakhir kegiatan inti.

- Pada pemberian tugas mengisi tabel pengamatan mengenai pengertian cerpen serta unsur-unsur intrinsik dan ekstrinsik cerpen: Guru memberikan tugas pengamatan mengenai materi pembelajaran.

- Pada saat pembimbingan guru selama siswa menjawab pertanyaan: Guru memberikan arahan kepada siswa untuk mengungkapkan alasan mengenai pendapat mereka.

- Penggunaan metode mengajar tanya jawab, diskusi, penugasan, think pair share: Ke empat metode pembelajaran tersebut dijalankan oleh guru ketika pembelajaran berlangsung dari awal sampai akhir.

- Penguasaan materi oleh siswa: Sebanyak $100 \%$ siswa kelas IX-C dapat memperoleh hasil diatas KKM hal maka dari itu tidak perlu diadakan perbaikan pembelajaran lagi.

- Aktivitas siswa: beberapa peserta didik mulai menunjukan ke aktifan dalam proses pembelajaran dan sudah berani untuk mengutarakan pendapatnya.

- Penggunaan waktu: Guru menggunakan efektifitas waktu dalam membagi antara kegiatan awal, inti, dan penutup dengan baik.

- Pemberian evaluasi formatif: Soal yang diberikan kepada siswa sebagai latihan yaitu sebanyak 5 soal sebagai penguji keberhasilan pembelajaran.

- Pemberian PR: PR yang diberikan guru sebanyak 5 buah dengan bentuk uraian untuk meningkatkan pemahaman mereka.

- Media alat peraga dalam pembelajaran: Tersedianya media yang digunakan berupa Slide Power Point, Kertas HVS, Pensil dan Alat-alat lain penunjang pembelajaran.

Setelah seluruh tahapan pelaksanaan kegiatan siklus 2 terlaksana. Pada siklus ke II ini menghasilkan jumlah nilai peserta didik yang didapat setelah kegiatan pembelajaran. Hasil nilai peserta didik dijabarkan sebagai berikut: Semua peserta didik sebanyak 24 orang berhasil memperoleh nilai diatas nilai ketuntasan kelas atau sebanyak 100\%. Dengan rincian peserta didik yang berhasil melampaui nilai ketuntasan kelas berjumlah $5(20,83 \%)$ nilai peserta didik yang mendapat 90 , peserta didik dengan perolehan nilai 85 sebanyak 3 orang (12,5\%), peserta didik dengan perolehan nilai 80 sebanyak 6 orang (25\%), siswa dengan nilai 75 sebanyak 3 orang $(12,5 \%)$, peserta didik dengan nilai 70 sebanyak 8 orang (33,33\%). Adapun nilai tertingginya yaitu 90 dan nilai paling kurang yaitu 70 sehingga tidak ada siswa yang nilainya dibawah nilai ketuntasan kelas. Hasil Rekapitulasi pencapaian hasil belajar peserta didik kelas IX-C SMPN 1 Cimenyan digambarkan dalam grafik di bawah ini. 


\section{REKAP NILAI PRA-SIKLUS, SIKLUS 1 DAN SIKLUS 2}

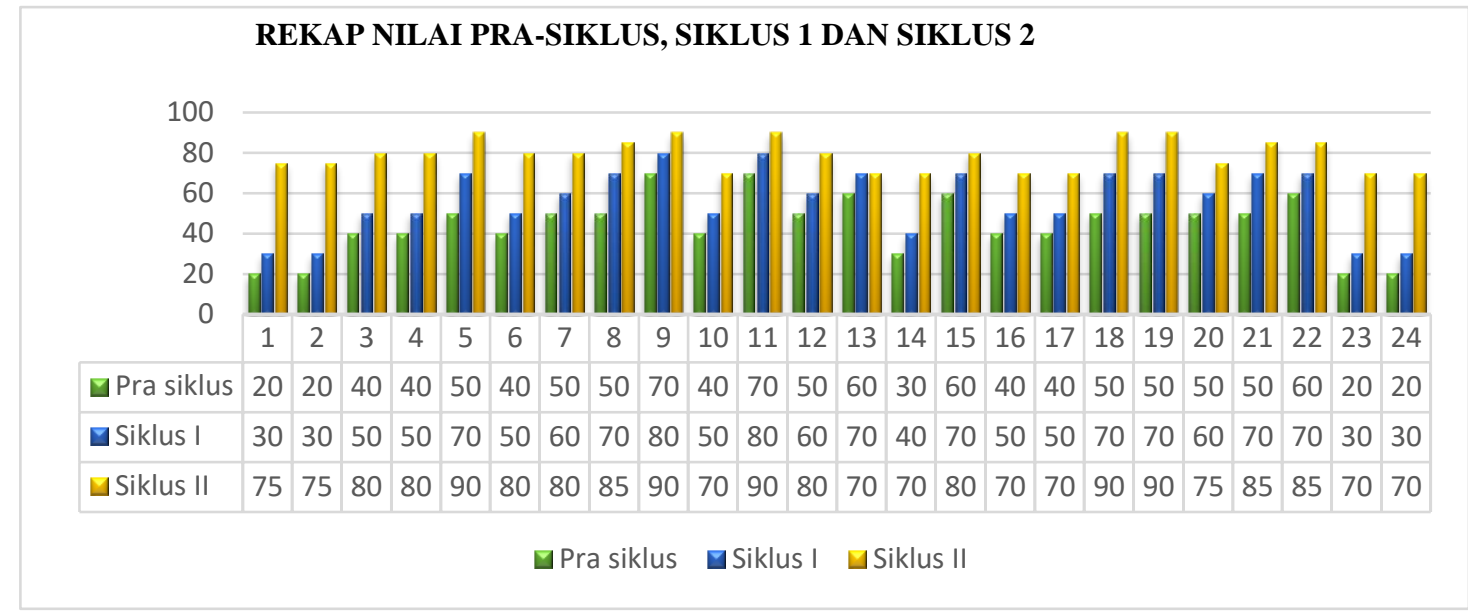

\section{Pembahasan}

\section{Hasil Belajar Siswa Meningkat}

Meneurut Teori taksonomi Bloom dalam Sudjana (2005) hasil belajar meliputi tiga aspek anatara lian, aspek kognitif, aspek afektif, dan aspek psikomotorik. Pertama yaitu apek kognitif, aspek ini berkaitan dengan hasil belajar berupa pengetahuan, hasil belajar pemahaman, hasil belajar penerapan, analisis sintesis, dan penilaian. Kedua yaitu raspek afektif, aspek ini berkaiatan dengan prilaku sikap serta nilai. Selain itu aspek afektif ini juga mempunyai tingkatan jenjang kemampuan diantaranya kemampuan menerima, kemampuan menjawab atau reaksi, kemapuan menilai, kemampuan berorganisasi serta karakter yang berhubungan dengan suatu nilai. Yang terakhir yaitu aspek psikomotorik, aspek ini berhubungan dengan keterampilan motoric manusia dalam hal menghubungkan dan mengamati (neuromuscular). Selain itu menurut Howard Kingsley dalam Daryanto (2007: 102-124) Membagi 3 aspek dalam hasil belajar peserta didik, diantaranya keterampilan dan kebiasaan, kemudian adanya suatu proses pengetahuan dan penentuan penegertian, serta yang terakhir sikap dan cita-cita. Ini menunjukan hasil proses hasil belajar peserta didik harus melalui proses yang Panjang untuk menacapai suatu tujuan. Dalam penelitian ini hasil belajar peserta didik merupakan hasil skor sesudah dilakukan Tindakan menggunakan alat evaluasi berupa tes.

\section{Penggunaan Model Berpikir-Berpasangan-Berbagi (Think Pair Share) Dalam Pembelajaran Cerpen}

Menurut Anita Lie (2010) Model pembelajaran think pair share ini mulai berkembang oleh Frank Lyman dari Universitas Maryland tahun 1985). Pertama Model pembelajaran ini digunakan sebagai kegiatan pemebelajaran berupa gotong royong. Kemudian Model pembelajan think pair share juga lebih menekankan peserta didik bekerja secara kelompok atau berpasangan dan mengutamakan suatu Kerjasama antar peserta didik. Selain itu model pembelajaran ini juga memberikan peserta didik kesempatan untuk berfikir lebih banyak, menjawab berdasarkan hasil temuannya serta bekerjasama dengan baik.

Menurut Agus Suprijono (2009) Pembelajaran model think pair share diawali dengan tahap thinking yaitu berfikir, tahap ini mengawali pemebelajaran dengan cara guru mengajukan beberapa pertanyaan yang berhubungan dengan pelajaran, kemudian peserta didik diarahkan untuk berfikir sesuai kemampuannya tentang isu tersebut. Tahap selanjutnya yaitu Pairing tahap berpasangangan, tahap ini guru memeberikan kesempatan kepada siswa untuk mencari pasangan dan membentuk kelompok dua orang. Pada tahap ini juga guru memberikan kesempatan kepada peserta didik untuk berdiskusi berbagi ilmu dengan temannya untuk menyelesaiakan permasalahannya. Tahap terakhir yaitu tahap sharing, tahap ini adalah tahap lanjutan dari diskusi hasil pemikiran kelompok yang di bagikan kepada kelompok lainnya sehingga terjadi suatu tanya jawab yang mengkatifkan suasana 
kelas dan pada akhirnya hasil belajar pun dapat meningkat seiring berjalannya proses pembelajaran yang aktif.

Berdasarkan hasil penelitian pada siswa kelas IX-C SMP Negeri 1 Cimenyan dengan menggunakan model think pair and share pada materi pembelajaran cerpen memiliki hasil yang sangat baik dan efektif. Ini dibuktikan dengan adanya peningkatan selama proses pembelajaran dari siklus I yang hanya $42 \%$ tingkat keberhasilannya menjadi $100 \%$ pada siklus II dan dapat disimpulkan ketuntasan belajar telah tercapai.

\section{Meningkatnya pengelolaan kelas oleh guru dan aktivitas siswa}

Berdasarkan hasil pengamatan teman sejawat dan perhitungan lainnya, didapatkan bahwa kegiatan peserta didik selama proses pembelajaran meningkat, selain itu proses pembelajaran yang dilakukan oleh guru selama mengelola kelas dalam setiap siklusnya mengalami perubahan yang lebih baik dari pembelajaran yang kurang aktif menjadi pembelajaran yang aktif sehingga hal ini sangat berdampak positif terhadap peningkatan kenaikan nilai peserta didik IX-C SMP Negeri 1 Cimenyan dalam proses pembelajaran tersebut.

\section{KESIMPULAN DAN SARAN}

Berdasarkan hasil penelitian dalam proses pembelajaran anatara siswa dan guru dapat disimpulkan bahwa perubahan pada pembelajaran menggunakan model pemebalajarn think pair and share ditunjukan adanyan perubahan nilai hasil belajar peserta didik selama proses pembelajaran selama siklus i dan ii. Selain itu pengelolaan kelas juga terlihat meningkat selama persiklus nya. Ini terlihat dari hasil observas aktivitas guru yang dilakukan peneliti dengan observer. Sehingga dapat disimpulkan pembelajaran menggunakan model think pair share berhasil dalam pembelajaran cerpen meningkatkan hasil belajar siswa kelas IX-C SMP Negeri 1 Cimenyan.

Sebagai seorang pengajar guru diharuskan untuk lebih kreatif dalam memilih model pembelajaran yang cocok dengan kebutuhan peserta didik. Pembelajaran yang efektif dapat meningkatakan aktivitas pembelajaran peserta didik. Khususnya dalam pembelajaran menggunakan model pembelajaran think pair share seorang guru harus memberikan kesempatan lebih kepada peserta didik untuk mengungkapkan pendapat dan hasil pemikirannya.

\section{DAFTAR PUSTAKA}

Agus Suprijono. (2011). Model-Model Pembelajaran. Jakarta: Gramedia Pustaka Jaya

Daryanto. (2007). "Peningkatan Keterampilan Membaca Pemahaman Cerpen dengan Metode Think pair and share pada Siswa Kelas IX SMP Negeri 2 Cepiring Tahun Ajaran 2009/2010." Skripsi. Universitas Negeri Semarang.

Frank, Lyman. (1985). Model Pembelajaran TPS. Jakarta: Universitas Maryland

Ibrahim, Muslimin, dkk. (2005). Pembelajaran Kooperatif. Surabaya: University Press. UNESA

Ihsan, Muhammad (2010) "Penerapan model think pair share (TPS) untuk meningkatkan motivasi dan hasil belajar siswa pada mata pelajaran bahasa Indonesia kelas X di SMK Bina Cendika Malang" Skripsi Universitas Negeri Malang 2010- Abstrak

Purnama, Desy (2016) "Pengaruh Model Pembelajaran Kooperatif Tipe Think Pair Share (Tps) Terhadap Aktivitas Belajar Siswa SMA NEGERI 1 KATAPANG Tahun Ajaran 2016/2017” Skripsi(S1) thesis, FKIP Unpas

Risnawati. (2005). Penerapan Pembelajaran Berdasarkan Masalah Melalui Metode Belajar Kooperatif Think-Pair-Share untuk Meningkatkan Motivasi dan Hasil Belajar Biologi Siswa Kelas 1 SMA Negeri 9 Malang"Skripsi UNM. 
Sudjana.N (2001). Peningkatan pemahaman Cerita Pendek dengan Metode Pemberian Tugas pada Siswa Kelas II SLTP N 2 Bonang Kabupaten Demak Tahun Ajaran 2000/2001. Skripsi. Unversitas Negeri Semarang.

Susilo. (2007). Penelitian Tindakan Kelas. Yogyakarta: Pustaka Book Publisher Wardani, dkk. (2011). Teknik Menulis Karya Ilmiah. Jakarta: Universitas Terbuka

Yustitia, V., Rusminati, S.H., \& Sulistyawati, I. (2014). Implementasi Lesson Study Menggunakan Model Think Pair Share Dan Pendekatan Saintifik. Premiere Educandum: Jurnal Pendidikan Dasar dan Pembelajaran 8, 1 